\title{
Development and performance evaluation of prototype single row gladiolus planter
}

Padam Singh, Triveni Prasad Singh and Ashutosh Mishra

Received : 13.10.2017; Revised : 08.03.2018; Accepted : 20.03.2018

See end of the Paper for authors' affiliation

Correspondence to :

Padam Singh College of Forestry, Veer Chandra Singh Garhwali Uttarakhand University of Horticulture and Forestry, Ranichauri, Tehri Garhwal (Uttarakhand) India Email : padamsingh1990@ gmail.com
-ABSTRACT : Gladiolus is also known as "queen of the flowers" is an important cash horticultural crop. Generally it is planted manually which is very tedious, time consuming and labor intensive operation. So far, there is no planter available for planting of gladiolus corms. With a view of mechanize the planting operation of this horticultural crop, atractor one of the popular bulbous ornamental plants. Traditionally the gladiolus corm are planted manually which is very high tedious, time consuming and labour intensive operation. A single row tractor operated prototype planter was developed to improve planting efficiency and reduce drudgery involved in manual planting method and its performance was evaluated in actual field condition. The three levels were selected for corm spacing viz., 15, 20 and $25 \mathrm{~cm}$ and three for forward speed viz., 1.0, 1.5 and $2.0 \mathrm{~km} / \mathrm{h}$ were taken as performance parameter for the developed prototype planter. The indicator namely missing index, multiple index, mechanical damage, corm spacing per meter length and properties of gladiolus corms etc. determined during the test.

- KEY WORDS : Co-efficient of uniformity, Corm spacing, Field capacity, Gladiolus planter

- HOW TO CITE THIS PAPER : Singh, Padam, Singh, Triveni Prasad and Mishra, Ashutosh (2018). Development and performance evaluation of prototype single row gladiolus planter. Internat. J. Agric. Engg., 11(1) : 227-232, DOI: 10.15740/HAS/IJAE/11.1/227-232. 